\title{
3 Center Stage: The Crucial Role of Macrophytes in Regulating Trophic Interactions in Shallow Lake Wetlands
}

Romi L. Burks, Gabi MulderiJ, Elisabeth Gross, Iwan Jones, Lene Jacobsen, ERIK Jeppesen, and Ellen Van Donk

\subsection{Introduction}

Hydrophilic, or water-loving, macrophytes characterize wetland ecosystems, indicating prerequisite conditions of hydric soils and sufficient hydrology. The presence of such macrophytes is a key descriptor in multiple wetland definitions (Lewis 2001a) and macrophytes may be further used to actually describe particular types of wetlands, such as cattail marshes. Macrophytes contribute significant biomass to wetland systems and represent a critical component of wetland biogeochemistry as primary producers and drivers of organic matter cycling within aquatic systems. In this chapter, we argue that macrophytes occupy the center of trophic interactions in shallow lakes, influencing outcomes through structural, behavioral and chemical interactions. We define shallow lakes as permanently flooded wetlands that often contain submerged or floating macrophytes and that may be surrounded by emergent vegetation (i.e. marshy habitat). Shallow remains a relative term in limnology circles, but typically is less than $3 \mathrm{~m}$ average depth, such that macrophytes can fill a substantial portion of the water column and stratification is neither predictable nor long-term. Such systems may be termed lakes, ponds or wetlands, depending on their size and the ecological context. Macrophytes may regulate trophic interactions in ephemeral systems without permanent inundation. 


\subsection{Central Position of Aquatic Vegetation}

Terrestrial ecologists historically have focused on vegetation. However, early aquatic studies also noted the dominance of plants in aquatic systems. For example, in The lake as a microcosm, Forbes (1925) derided areas'clogged with weeds', but then elaborated on how these weeds (Chara, Potamogeton, Ceratophyllum) swarmed with life, including fishes, invertebrates, zooplankton and algae. Lindeman (1942) included pondweeds as an important component of lake food webs and Teal (1962) went a step further and quantified the energy flow between trophic levels in a salt marsh. Thus, historical precedent exists for focusing attention on macrophytes as part of the aquatic community. First to emphasize ecosystem processes, Carpenter and Lodge (1986) summarized the impacts of submerged macrophytes on abiotic and biotic components of aquatic systems. With a similar aim, Jeppesen et al. (1997a) published a comprehensive book documenting the structuring role of submerged macrophytes in lakes. We extend their discussion of trophic interactions and also consider other macrophyte architectures (i.e. floating-leaved, emergent, freely-floating).

Reinforced by multiple mechanisms, macrophytes promote water clarity, help stabilize a clear-water state (Jeppesen 1998; Scheffer 1998) and enhance biodiversity (Declerck et al.2005). Several of those feedbacks depend on structural or chemical effects that, in turn, influence behaviors of multiple trophic levels. To evaluate our progress in understanding the role of macrophytes in wetland systems since Jeppesen et al. (1997a), we performed an extensive literature search (1997-2004) regarding aquatic macrophytes. Using four search engines [Web of Science, Science Direct (Elsevier), BioOne, Kluwer-Online] our inquiry discovered 126 papers that involved trophic interactions with macrophytes.

The vast majority ( $74 \%)$ of recent studies focused on behavioral interactions with macrophytes, with an additional $13 \%$ exploring this within a chemical context. The remaining $13 \%$ focused on single structural-chemical interactions, largely between macrophytes and phytoplankton. Macrophytes, fish and zooplankton composed the most common suite of organisms studied together (12\%), although $35 \%$ of the studies involved three groups and $56 \%$ only examined a single interaction. Thirteen studies $(10 \%)$ examined more complex food webs in shallow wetland systems; however, only four of these studies (3\%) examined five trophic levels. Surprisingly, similar numbers of single-interaction studies involved both fish and invertebrates, dominated by studies including fish ( $44 \%$ ). Only $10 \%$ of the studies included an additional primary producer (periphyton or phytoplankton) besides macrophytes. These complex trophic connections that occur with macrophytes dramatically alter the carbon flow through the system (Fig. 3.1). With this context, we used the literature survey to identify four key themes regarding the regulation of trophic interactions by macrophytes. 
Without macrophytes

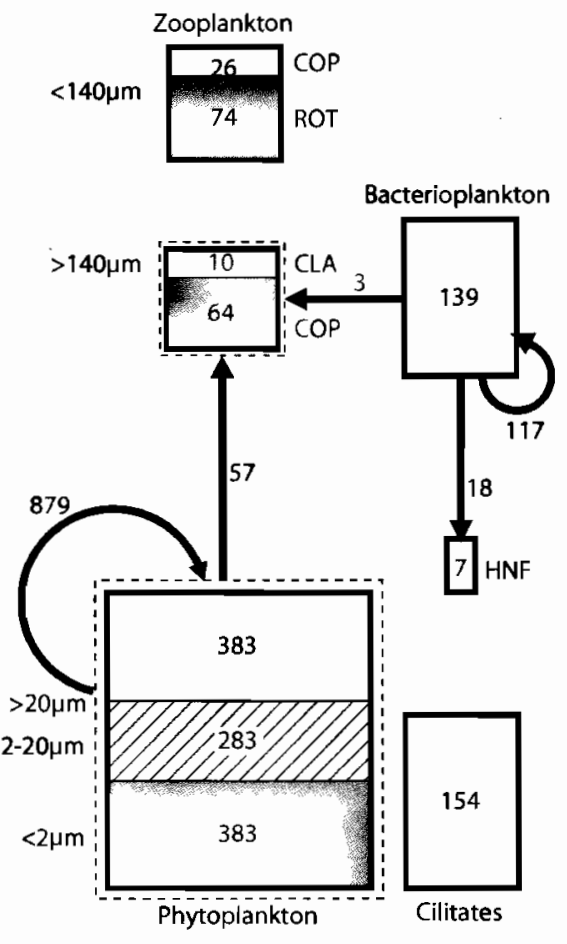

With macrophytes

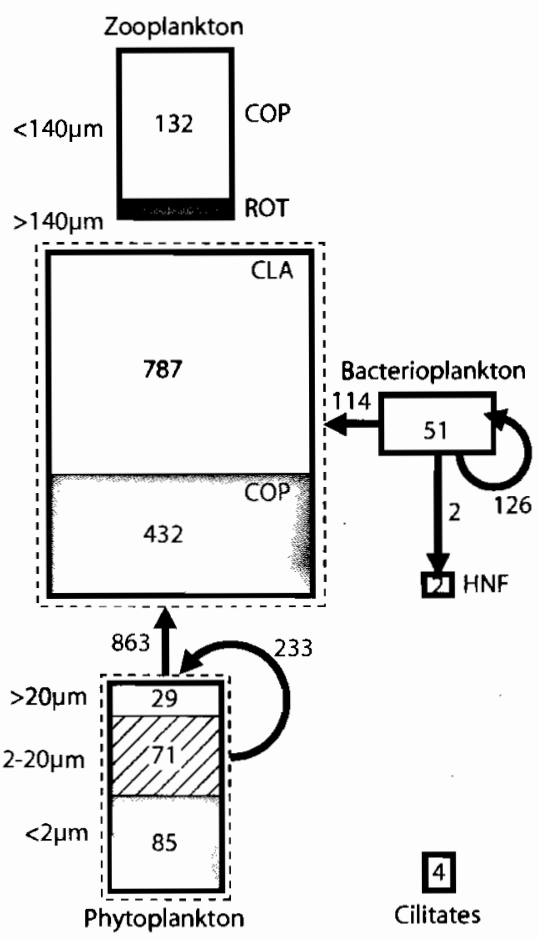

Fig. 3.1 Illustration of the dramatic alteration of energy flow in the presence of macrophytes (originally published by Jeppesen et al. 2002). The figure illustrates the cascading trophic interactions within enclosures placed in the littoral zone of a shallow Danish lake (Stigsholm). The data illustrate carbon flow between trophic levels in enclosures with and without submerged macrophytes for the first diel periods where day and night sampling occurred. Boxes represent the biomass ( $\mu \mathrm{g} \mathrm{C}^{-1}$ ) of different trophic components and the arrows measure flux per day. COP Copepods, largely cyclopoids, ROT rotifers, $C L A$ cladocerans, $H N F$ heterotrophic nanoflagellates. Broken box outlines indicate that phytoplankton production and zooplankton grazing are community estimates for all groups within the boxes. Note that zooplankton grazing by far exceeded phytoplankton production in the macrophyte state, suggesting extremely high grazing on phytoplankton and likely benthic facilitation of the zooplankton. The latter may, in turn, ensure a steady high abundance of zooplankton and thus high grazing on phytoplankton when zooplankton migrate to the open water at night

\subsubsection{Central Themes: Zooplankton Depend on Macrophytes as Habitats}

While many historical studies noted the abundance of macroinvertebrates among macrophytes (e.g. for damselflies, see Lombardo 1997; for snails, see Brönmark and Vermaat 1997), fewer studies recognized the role of macro- 
phytes as providing refuge for zooplankton. Limnologists generally restrict their discussion of refuges for zooplankton to the hypolimnetic refuge provided by deep lakes for large-bodied zooplankton undergoing diel vertical migration (i.e. Daphnia). However, littoral-associated cladocerans (i.e. Alona, Chydorus, Simocephalus, Ceriodaphnia) commonly occur among macrophytes in large lacustrine wetlands (Hann and Zrum 1997) and small glacial kettleholes (Gaiser and Lang 1998). Recent studies from shallow lake and wetland systems demonstrated that macrophyte presence can bolster pelagic zooplankton, as large-bodied species such as Daphnia migrate horizontally into macrophytes to seek refuge from predators (for a review, see Burks et al. 2002).

Zooplankton dependence on macrophyte beds acts as a positive feedback mechanism that helps maintain clear-water conditions in lakes, especially eutrophic systems with high macrophyte biomass (Jeppesen et al. 1999; although see Blindow et al. 2000). Multiple scenarios exist, however, for the relationship between zooplankton size (at the individual or population scale) and macrophyte density. One possibility is a non-linear relationship based on the assumptions that increased prey size leads to increased vulnerability (Brooks and Dodson 1965) and that increased structural complexity makes foraging more difficult for some predators in a non-linear way (Jeppesen et al.1997a; Burks et al. 2001a). This refuge scenario suggests that some threshold of macrophytes is required, which is corroborated by a large mesocosm experiment that showed smaller rotifers and cyclopoid copepods comprised the zooplankton in plant-free controls while large-bodied cladocerans dominated enclosures with plants, when plant density exceeded a certain threshold (Fig. 3.1; Jeppesen et al. 1997a, 2002).

With horizontal migration, the extent of entry into macrophytes by zooplankton varies, depending on the costs of inhabiting macrophytes. These costs include competition with other zooplankton, food scarcity, chemical inhibition, or adverse abiotic conditions (Burks et al. 2002). Such costs might be responsible for the horizontal patchiness that occurred in Rybak and Weglenska's (2003) study, where sparse beds showed more limnetic species of Cladocera while dense beds held more littoral species. Intense predation pressure from macrophyte-associated invertebrates (Burks et al. 2001b) also may factor into the non-linear relationship between macrophyte density and zooplankton size and contribute to patterns commonly observed in the field. Invertebrate density across vertical and horizontal dimensions varies among macrophytes. The substantial surface area of submerged macrophytes likely supports higher abundances of macroinvertebrates than floating or emergent plants (Cattaneo et al. 1998). Marklund et al. (2001) found higher densities of invertebrate grazers in the layers closer to the sediment than near the surface of Chara beds. Their results also showed higher densities at the macrophytes' edge versus the innermost parts for some species. The latter corroborates earlier results by Lauridsen et al. (1996). Thus, for zooplankton, macrophyte beds 
may form a horizontal transition zone in predation, from invertebrate predation inshore to fish predation offshore (Tolonen et al. 2001).

The use of macrophytes as a refuge by zooplankton is also likely to decline with increasing turbidity. While several studies document the use of submerged and floating plants as a refuge, the ability of emergent plants to provide a refuge for zooplankton remains questionable. Nurminen and Horppila (2002) investigated the importance of emergent macrophytes as refugia for littoral cladocerans in lakes of differing trophic status. No tendency toward horizontal migration into emergent macrophytes occurred in a clearwater system. In the turbid system, Nurminen and Horppila (2002) found reverse migration by large-bodied filter feeders (Limnosida frontosa, Sida crystallina), possibly in response to high densities of small fishes among the vegetation. This agrees well with a recent study of changes along a chlorophyll $a$ (turbidity) gradient in the proportion of fish near the shore versus the open water. Numerous Danish lakes showed an increasing share of the most abundant fish species in the littoral as turbidity increased (Jeppesen et al. 2006). In contrast, the anti-predator behavior of juvenile fish, such as using macrophytes for refuge, may occur less frequently in turbid water, where hunting by sight-dependent predator fish is less successful (Abrahams and Kattenfeld 1997). Under clear-water conditions, juvenile pike (Esox lucius) spent more time foraging among complex structures compared to an even distribution between complexity and open water under turbid conditions (Skov et al. 2002). In a survey of 33 interconnected shallow ponds, Cottenie et al. (2001) found that zooplankton community structure depended strongly on predation intensity and macrophyte cover and that the clear-water state coincided with macrophytes, piscivorous fish and large Daphnia species.

Besides the influence of turbidity, the ability of macrophytes to serve as a refuge for zooplankton also declines when macrophytes play host to other predators, suggesting the avoidance of macrophytes by zooplankton. If one considers its root network, water hyacinth (Eichhornia crassipes) may possess a comparable surface area to submerged plants. However, Eichhornia does not support a similar high diversity of invertebrates, including zooplankton (Meerhoff et al. 2003). Lower colonization of macrophytes than predicted may be due to chemical deterrence (Burks et al. 2000, 2001a), differences in water chemistry from the floating plant canopy or high fish predation (Meerhoff et al. 2003 and unpublished results). However, the few studies on free-floating plants make such generalizations difficult and more research is needed to understand if this architectural type differs in function from submerged or emergent macrophytes. Despite any potential differences, high fish predation can occur outside all types of macrophyte architectures. Romare et al. (2003), for example, found that roach (Rutilus rutilus) and perch (Perca fluviatilis) congregated outside dense emergent vegetation in a small Danish lake, thus likely eliminating the advantage of horizontal migration for cladocerans. This negative relationship may exist with the carnivorous macrophyte bladder- 
wort, Utricularia (Guisande 2000; Englund and Harms 2003), depending on zooplankton size. Furthermore, larval dragonflies also pose a serious predation threat to zooplankton undergoing diel horizontal migration, particularly at low macrophyte densities (Burks et al. 2001b). Alternatively, littoral fishes may reinforce the refuge effect for zooplankton if they prefer macroinvertebrates (Sagrario and Balseiro 2003). Overall, macrophytes act as effective refuges for zooplankton or planktivorous fishes when the diversity or density is sufficient enough to depress the predation rates of planktivores (Priyadarshana et al.2001) or piscivores, respectively (e.g.largemouth bass, Micropterus salmoides;Valley and Bremigan 2002). Further experiments and field studies that investigate patterns of zooplankton size, macrophyte density and composition will help resolve the ambiguity associated with these multiple scenarios and lend further insight into how carbon cycling occurs across multiple trophic interactions (Fig. 3.1).

\subsubsection{Central Themes: Chemical Ecology Spans Trophic Levels}

Biochemical interactions between (submerged) macrophytes and competing primary producers, termed 'allelopathy' (sensu Molisch 1937), often appear in the literature, but at the same time ignite much controversy. Allelopathy is unlikely to act as a determining factor of a clear versus turbid state, but it certainly influences the interactions between the main opponents. Multiple laboratory studies document inhibitory effects of extracts, exudates or intact macrophytes on algae (summarized e.g. in Gross 2003a; for a recent example from freely-floating plants, see Mulderij et al. 2005a). Most studies show differential sensitivity among algal groups, with cyanobacteria often the most sensitive and chlorophytes and diatoms less susceptible (e.g. Gross et al.1996; but see Mulderij et al. 2005b). Macroalgae, such as charophytes, also employ allelopathic chemicals in their interactions with other primary producers (Van Donk and van de Bund 2002; Mulderij et al.2003). Relative to other macrophyte growth forms, the likelihood of allelopathic interactions increases in dense stands of submerged macrophytes where more stagnant water prevails. Based on our literature survey, we provide a ranked list of macrophy te species that we think best represent allelopathic species (Table 3.1).

Knowledge of chemical ecology in freshwater systems lags behind marine and terrestrial systems (Burks and Lodge 2002), but we see substantial progress. Our literature survey indicated that $25 \%$ of recent studies included an aspect of chemical influence, suggesting that more investigations of this nature are underway. The practicality of both realistic laboratory and in situ experiments will increase as we identify more compounds. For now, we noticed particularly the variety of ways in which chemical cues or allelopathic compounds altered trophic interactions. The impacts often depended on species identity and commonly involved macroinvertebrates. 
Table 3.1 Ranking allelopathic potential of aquatic macrophytes (based on evidence presented in studies cited by Wium-Andersen 1987; Gopal and Goel 1993; Gross 2003a). Evidence was considered high when different authors reported the same or similar observations and/or when proof for the release of active compounds occurred. The asterisk (*) indicates that evidence was not as strong as for "high" species. Note that not all Chara species showed indications of allelopathic properties

\begin{tabular}{l|ll}
\hline $\begin{array}{l}\text { Allelopathic } \\
\text { potential }\end{array}$ & Species & Common name \\
\hline $\begin{array}{l}\text { High } \\
\downarrow\end{array}$ & $\begin{array}{l}\text { Myriophyllum spicatum } \\
\text { Chara globularis, Ch. aspera, } \\
\text { Ch. contraria }\end{array}$ & $\begin{array}{l}\text { Eurasian water milfoil } \\
\text { Stonewort or charophyte }\end{array}$ \\
$\downarrow$ & Ceratophyllum demersum & Coontail \\
$\downarrow$ & Stratiotes aloides & Water soldier \\
Medium/high* & Elodea spp & Waterweed, water pest \\
$\downarrow$ & Eleocharis acicularis & Spike rush \\
$\downarrow$ & Myriophyllum brasiliense & Parrotfeather, Brasilian milfoil \\
$\downarrow$ & Myriophyllum verticillatum & Whorl-leaf watermilfoil \\
Medium & Berula erecta (Sium erectum) & Water parsnip \\
$\downarrow$ & Eichhornia crassipes & Water hyacinth \\
$\downarrow$ & Egeria densa & Common waterweed \\
$\downarrow$ & Najas marina ssp. intermedia & Spiny naiad \\
$\downarrow$ & Nuphar lutea & Yellow water lily \\
Low & Potamogeton spp & Pondweeds \\
\hline & &
\end{tabular}

Some species showed higher tendencies to be allelopathic than others (Table 3.1). For example, Körner and Nicklisch (2002) demonstrated that Myriophyllum spicatum and Ceratophyllum demersum both inhibited photosystem II activity of phytoplankton, but they found no effect by Potamogeton pectinatus. Based on the absence of plant fragments in fish guts, Nurminen et al. (2003) also implied selective avoidance of the first two species (M. spicatum, C. demersum) by rudd (Scardinius erythrophthalmus). Macrophyte species may influence both behavioral and chemical interactions. For example, water incubated with Stratiotes (i.e. water soldier) demonstrated a highly significant inhibitory effect on the green alga Scenedesmus obliquus (Mulderij et al. 2005a), cyanobacterium Microcystis and eustigmatophyte Nannochloropsis (Mulderij et al. 2005b). Furthermore, the presence of Stratiotes aloides, especially young plants, increased colony formation by $S$. obliquus. Sinking rates of the algae also increased, leading to improved water clarity and light conditions for the macrophyte (Mulderij et al.2005a). In the reverse direction, cyanobacterial compounds can have detrimental impacts on submerged vegetation. For example, Microcystin-LR shows allelopathic properties against $M$. spicatum and C. demersum (Pflugmacher 2002). 
The deterrent chemical nature of some macrophytes may strongly regulate the biological community. One study suggests that aquatic plants repellent to grass carp could serve as areas of amphibian rehabilitation (Murphy et al. 2002). Endangered odonate larvae (Aeshna viridis) also preferred Stratiotes aloides, as it also served as a refuge from perch predation (Rantala et al. 2004). Other work connects herbivores and predators through the chemical nature of the macrophyte. For example, Hyallela azteca (Amphipoda) readily grazes on roots of emergent macrophytes (Berula erecta, water parsnip), even though they may be chemically defended (Rowell and Blinn 2003). Consequently, these amphipods exhibited lower susceptibility to fish predation. Although common in the marine literature, this study provided the first experimental evidence of reduced predation on a freshwater herbivore that consumed a chemically defended plant (Rowell and Blinn 2003).

Of all the aquatic macrophytes, one species (Myriophyllum spicatum, Eurasian watermilfoil; EWM) clearly stood out as the most influential chemically (Table 3.1) because of multiple interactions that occur with herbivores and competing phototrophs. On the whole-lake scale, macroinvertebrate biomass on dominant plant species in a lake may decline as the percentage of EWM cover increases (Cheruvelil et al. 2001). Furthermore, Lindén and Lehtiniemi (2005) found that chemicals excreted by dense EWM resulted in high mortality (73-89\%) of mysids (Neomysis integer, Praunus felxuosus) and lowered the feeding efficiencies of three-spined sticklebacks (Gasterosteus aculeatus). At a smaller scale, Acentria (Lepidoptera) exhibited higher feeding rates on Myriophyllum than on Elodea (Gross et al. 2001). In choice experiments, Acentria larvae clearly preferred EWM. By selectively removing apical tissue with the highest concentrations of allelopathically active compounds (Choi et al. 2002), herbivory by Acentria might weaken the allelopathic strength of this species, indirectly altering competitive interactions and the plant's susceptibility to bacterial infection. Overall, the magnitude of herbivory on EWM may shape competitive interactions between submerged macrophytes, change invertebrate biomass and perhaps alter ecosystem processes, such as primary production (Gross 2003a).

Remarkably, many invasive species, such as $M$. spicatum in Northern America or Elodea spp in Europe (Gross et al. 1996; Erhard and Gross 2005), act as allelopathically active species (Table 3.1 ). Significant differences in allelopathic activity between native and invasive specimens remain uncertain for aquatic systems, although Bais et al. (2003) documented such an occurrence with invasive, spotted knapweed (Centaurea maculosa). In addition, the extent to which allelopathic interactions add significantly to successful invasion also merits further attention. The concentration of active compounds in EWM may vary strongly, depending on environmental conditions (Gross $2003 \mathrm{~b}$ ) and may vary between native and invaded ranges of plants. Therefore, the role of macrophytes as chemical signalers under field conditions strongly depends on the macrophyte species present, the density or spatial heterogene- 
ity of their patches, the velocity of breakdown of active compounds and possibly the nutrient state of both donor (macrophyte) and target organisms (e.g. phytoplankton).

The magnitude of the deterrent effect of macrophytes on trophic interactions also may differ among species and in the presence of other predatory cues. For example, Daphnia actively avoided submerged macrophytes in the absence of fish, but then overcame this repellency and sought refuge when fish arrived (Burks et al. 2001a), despite the possible costs of reduced zooplankton growth (Burks et al. 2000). In the absence of fish, Van de Meutter et al. (2004a) found an additional, although weak, avoidance of macrophytes that housed Ischnura elegans ( $10 \%$ less within vegetation). Unfortunately, the predictability of macrophyte avoidance by Daphnia varies, perhaps depending on the clone, the presence of conspecific cues or the presence of other predators. In a similar study, Van de Meutter et al. (2004b) found no horizontal migration response toward the open water in the presence of Ischnura elegans alone. However, when Ischnura co-occurred with Chaoborus, daphnids showed an increased avoidance of plants. Van de Meutter et al. (2004b) attributed this to an increased risk of predation in the vegetation. If strong enough, chemical cues from littoral predators may contribute to the already repellent nature of macrophytes and override the tendency for zooplankton to seek refuge from fish, suggesting a hierarchal nature of chemical cues.

\subsubsection{Central Themes: Impacts of Grazer-Epiphyton Interactions with Macrophytes}

Although the term periphyton encompasses the whole community of organisms that colonize surfaces, we use epiphyton to stress the competitive interactions between algae and macrophytes. Macrophytes can serve as a habitat, a refuge from predators, or can act as a substrate which potential food sources can colonize (Fig. 3.2). Most epiphytes belong to the classes Bacilliophyta (diatoms) and Chlorophyta (green algae), but nuisance, grazing-resistant forms, such as filamentous blue-greens (Cyanobacteria) and Cladophora, can occur when the community is grazed by invertebrates which are selective in their feeding (Jones et al. 2000). Snail densities on macrophytes depend in part on plant palatability, periphyton density and algal quality and growth form (Brönmark and Vermaat 1997; Jones et al. 2000; Lombardo and Cooke 2002). Besides snails, other insects (including caddisflies, mayflies, beetles, corixids), along with several crustaceans (e.g. amphipods, cladocerans, ostracods) consume ample amounts of epiphyton (Jones et al. 1997).

We often recognize the importance of top-down control of phytoplankton by zooplankton grazing and its central role in maintaining the clear-water state (Jeppesen et al. 1997b). However, the distinction between the origin and maintenance of alternative equilibria is often not made; and it may be that 
Sedimentation

Denitrification

Dominance of ciear water

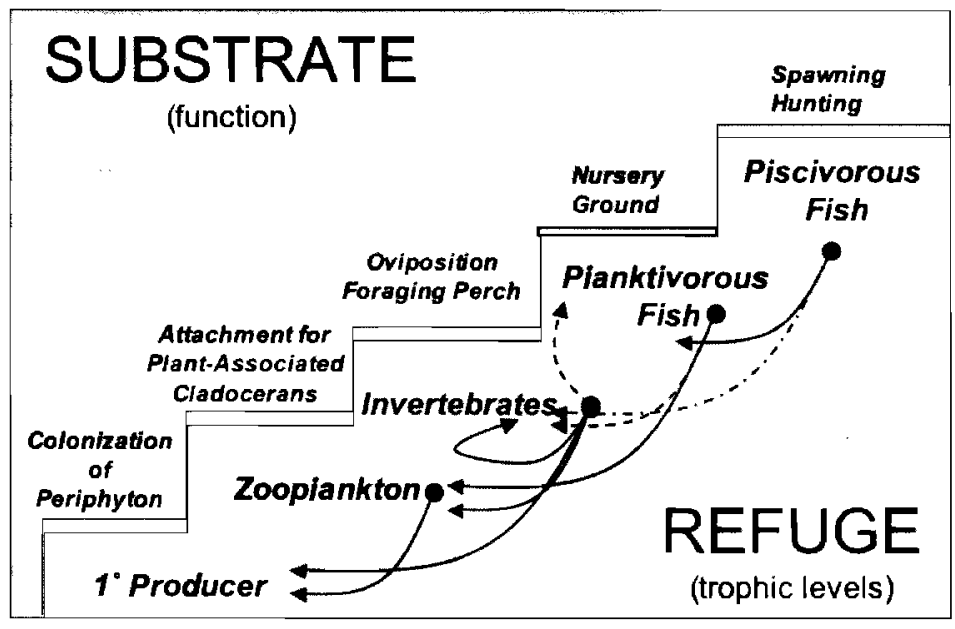

\section{Turbidity Resuspension Wave Action}

\section{Prevalence of Macrophytes (increasing $\rightarrow$ )}

Fig. 3.2 Multi-faceted dual roles of macrophytes as both refuge and substrate across trophic levels. The steps suggest that the refuge potential of macrophytes increases with increasing macrophyte density after a threshold is established (i.e. the plateaus). Arrows show the predator-prey relationships that necessitate the need for macrophyte refuge. Solid lines illustrate the most predicted prey choice (origin with predator, arrow points to prey). Dotted lines illustrate prey choices that could occur with ontogenetic diet shifts. Four arrows originate from invertebrates because of the versatility of functional groups (i.e. predators, grazers, filterers). Increasing refuge provided by macrophytes leads to sedimentation and the dominance of clear-water, while the absence of macrophytes increases turbidity and promotes wave action and resuspension

phytoplankton plays a less important role in precipitating the shift from a turbid to a clear-water state. Macrophytes lead to increased sedimentation, through reduced water movement, which results in an influx of particles to the sediment. Consequently, there is less phytoplankton available to zooplankton in macrophytes, thus increasing the importance of epiphyton. Traditional approaches centered on the response of epiphyton to increased nutrient availability (Phillips et al. 1978), but recent work provides insight into how higher trophic levels affect the interaction between periphyton and plants, and accordingly shallow lake function.

Shading by periphyton shortened the clear-water phase associated with optimum growth conditions for submerged plants (e.g. P. pectinatus) in Lake Müggelsee (Germany; Roberts et al. 2003). Nutrients alone, however, do not 
appear to determine whether epiphyton can reach sufficient densities to negatively impact macrophytes. Experimental work suggests that other mechanisms are important for the loss of macrophytes (Jones et al. 2000; Williams et al. 2002). These experiments, previous work (Brönmark and Vermaat 1997) and a survey of 17 macrophyte-dominated lakes in the United Kingdom (Jones and Sayer 2003) have led to a proposal that the strength of a trophic cascade in the littoral zone determines the fate of macrophytes (Fig. 3.3). We agree with a recent review (Vadeboncoeur et al. 2002) that argued that benthic organisms, including epi- or periphyton and grazers, form integral links in lake food webs and deserve more emphasis in studies of trophic interaction.

In eutrophic to hypertrophic lakes, macrophyte biomass exhibits a negative relationship with epiphyton growth, with the density of epiphyton being, in turn, dependent on the density of grazing macroinvertebrates, but not nutrients (Fig. 3.3; Jones and Sayer 2003). A 20-fold increase in nutrient loading had no effect on the abundance of epiphyton growing on the surface of Elodea nuttallii in artificial ponds, whereas epiphyton density negatively correlated with increased grazers (Jones et al. 2002). In experimental ponds constructed to simulate reservoir wetlands, Balci and Kennedy (2003) also found that macroinvertebrate abundance correlated well with epiphyton biomass, although epiphyton biomass varied between exotic EWM and native water stargrass, Heteranthera dubia (Balci and Kennedy 2003). Fish biomass also served as a reliable predictor for the density of invertebrates (Jones and Sayer 2003) and accordingly epiphyton. Williams et al. (2002) showed that epiphyton chlorophyll $a$ in experimental mesocosms increased significantly with increasing fish biomass $\left(0-700 \mathrm{~kg} \mathrm{ha}^{-1}\right)$. Interestingly, Jones and Waldron (2003) found that the proportion of periphyton in the diets of zooplankton increased with fish density, possibly as a result of increased horizontal migration. For these reasons, we highlight the strong potential for epiphyton-grazer interactions with macrophytes, mediated through interactions with fish, to facilitate shifts between turbid and clear states (see Section 3.2.4).

Colonization by epiphytes generally places macrophytes at a substantial disadvantage, due to increased competition for light, nutrients and carbon (Jones et al. 2000; Williams et al. 2002). By continuously grooming macrophyte hosts of unwanted algae and sediments, grazers may help maintain littoral communities (James et al. 2000). The periphyton removal rate generally increases allometrically with grazer biomass (Jones et al. 1997). Most grazing studies focus on snails (Gastropoda, see Brönmark and Vermaat 1997) because they are among the largest and most visible grazers on aquatic plants and can remove substantial biomass. While it may be advantageous for macrophytes to host snails, Jones et al. (2000) suggest that it is unlikely that macrophytes alter the community composition of epiphytes to increase their attractiveness to snails. However, see Brönmark's (1985) study that showed how macrophyte exudates (dissolved organic matter excreted from Cerato- 


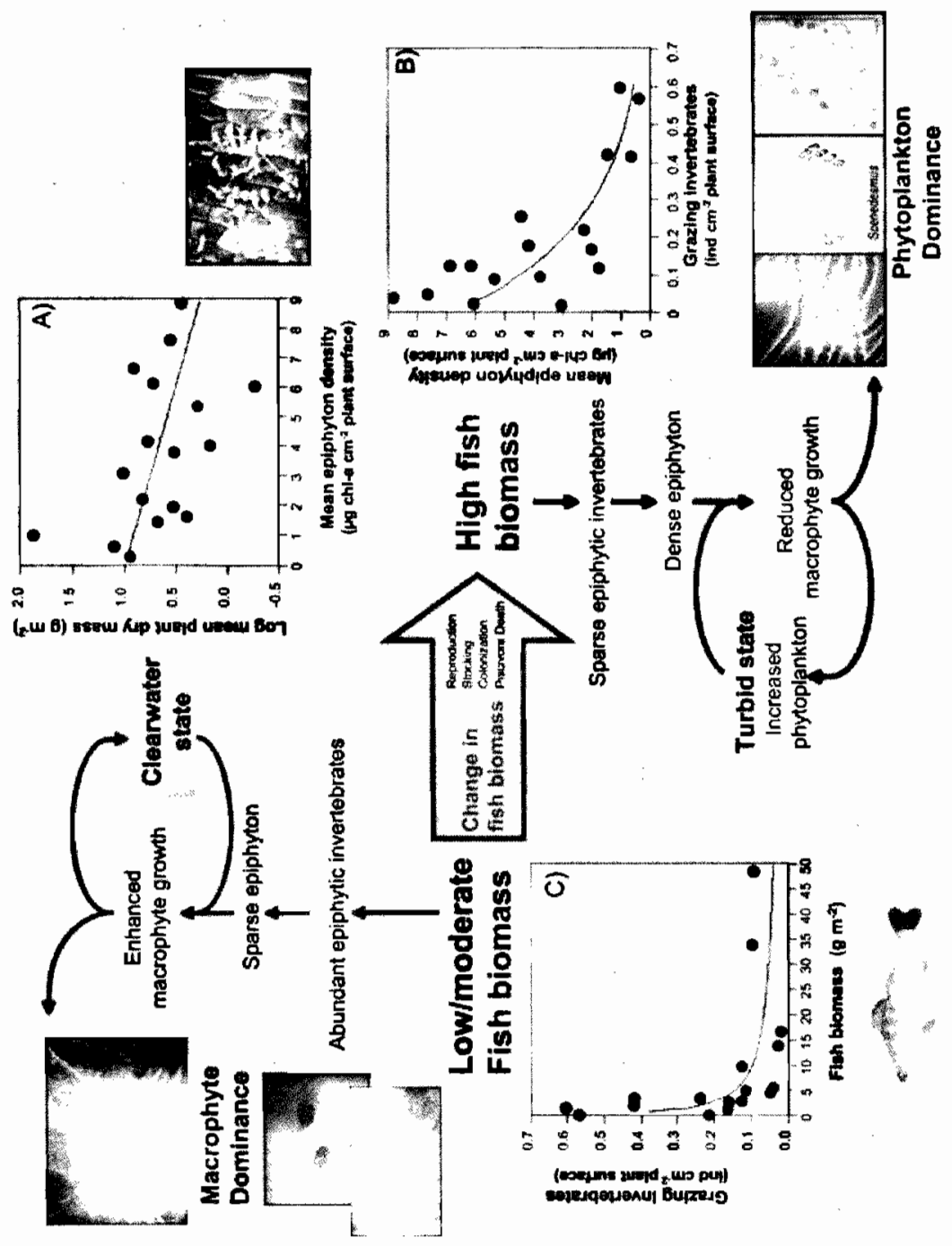

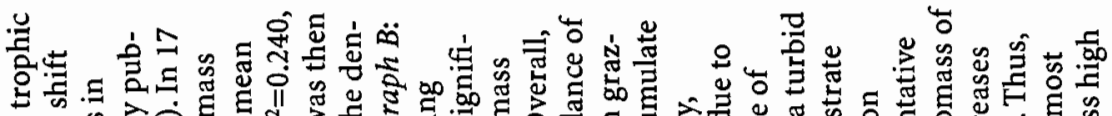

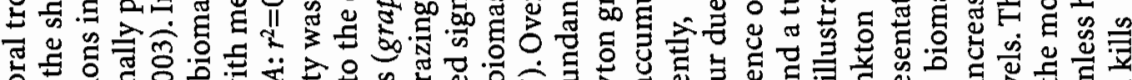

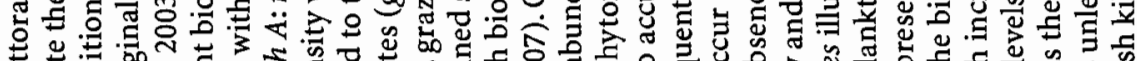

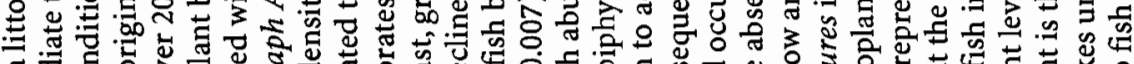

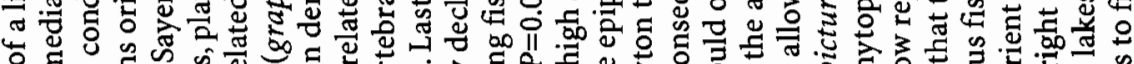

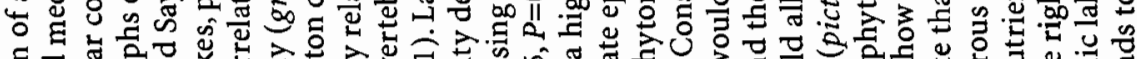

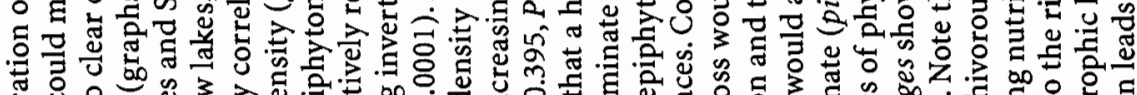

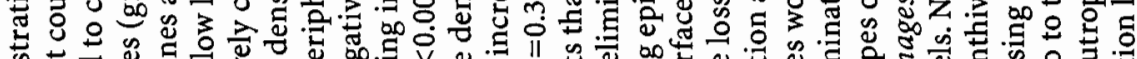

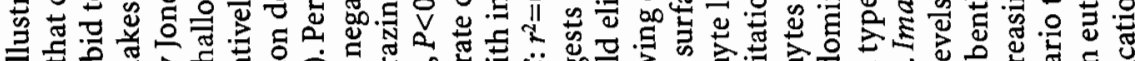

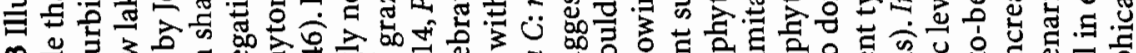
ผ च

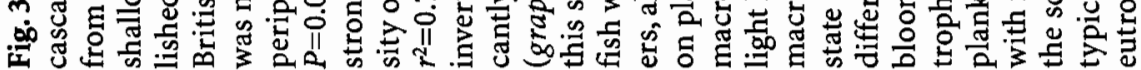


phyllum demersum) attracted periphyton grazers (i.e. the snail Lymnaea peregra).

Direct consumption of macrophytes also alters trophic interactions. Some large invertebrates, including the invasive channeled applesnail Pomacea canaliculata (Lach et al.2000) or crayfish (Lodge et al. 1994), may consume or destroy macrophytes copiously, decreasing the habitat available for colonization. For example, Procambarus clarkii reduced the macrophyte cover in a mesotrophic, Spanish shallow lake from $97 \%$ to below $10 \%$ in less than three years (Rodríguez et al. 2003). However, species-specific impacts occur, e.g. Hessen et al. (2004) demonstrated that the crayfish Astacus astacus failed to control rapid growth of Elodea. In addition, macrophytes differ in their palatability to snails and other invertebrates (Elger and Willby 2003), therefore changing plant species composition through selective herbivory (Elger et al. 2002).

The large size and omnivorous nature of crayfish differentiate them from other macroinvertebrates, underlining their importance in littoral habitats (Lodge et al. 1994). With a demonstrated preference for herbivory over carnivory and for native versus exotic macrophytes (i.e. Eichhornia), P. clarkii could be responsible for the extirpation of native aquatic macrophytes in Lake Naivasha, Kenya (Smart et al.2002). In small Michigan ponds, vascular macrophytes failed to establish in the presence of crayfish, blue-green algae came to dominate and two epiphy ton herbivores (i.e. tadpoles, snails) did not co-exist with crayfish (Dorn and Wojdak 2004). Beyond just consuming macrophytes, Dorn and Wojdak's (2004) study showed that crayfish preyed heavily on fish eggs, reducing fish recruitment (Fig. 3.2) and indirectly enhancing zooplankton biomass. Crayfish also influenced the life history traits and habitat choice of snails. Increased abundance led to the aggregation of snails on food-poor macrophytes and reduced snail growth (Lewis 2001b). Crayfish can structure the abundance and size distribution of thin-shelled snails through size-selective predation, although crayfish effects on snail size distribution may be less pronounced in complex habitats, such as macrophyte beds (Nyström and Pérez 1998). Collectively, these results indicate that crayfish can have dramatic direct and indirect impacts on littoral pond communities via feeding links with multiple trophic levels and non-trophic activities.

\subsubsection{Central Themes: Prevalance of Fish Influence in Shallow Lakes}

Tight coupling makes it challenging to discuss the role of macrophytes in shallow lakes without routinely acknowledging the prevalence of fishes in the littoral. Multiple interactions highlighted in our literature survey involved fish. Particular littoral fish communities exist in both temperate (Weaver et al. 1997; Lewin et al. 2004) and tropical systems (Vono and Barbosa 2001; Jeppesen et al. 2005). Such fishes spend their time predominately within macro- 
phyte beds, although the proportion of that time may change with ontogenetic shifts (Persson and Crowder 1997). For example, juvenile pike (Esox lucius) inhabit littoral vegetation, but as they grow larger, pike associate with open water along the edges of macrophyte beds (Bry 1996) or less complex structure(s) of emergent macrophytes (i.e. Typha; Skov and Berg 1999).

Apart from ontogenetic habitat shift, the time spent in the littoral by fish also varies on a diel and a seasonal scale (Romare et al. 2003). For instance, many juvenile littoral fish perform diel horizontal migrations into the open water at night (e.g. Jacobsen and Perrow 1998; Shoup et al. 2003). Limited knowledge exists regarding winter behavior in shallow lake fish, but the littoral structure might act as a winter refuge, possibly resulting in a lower ratio of zooplankton to phy toplankton compared to summer (Jeppesen et al. 2004). This suggests a lower potential for zooplankton grazing. Habitat use of macrophytes by lower taxa strongly depends on the presence and species identity of littoral fishes. As suggested earlier, the water clarity of the system also influences interactions between macrophytes and fish. For example, Jacobsen et al. (2004) showed roach hide under water lilies during daytime in a clear-water lake inhabited by piscivorous bird species. Therefore, floatingleaved macrophytes might provide an effective cover for fish if the predation threat comes from above.

Macrophytes also serve as substrate for spawning (Fig. 3.2; Winfield 2004). Pike prefer a short dense structure, even flooded grasslands, for spawning. As for several other species, eggs require a structure on which to adhere. Some fish even use vegetation for nest-building during spawning, especially large sticklebacks (Gasterosteus aculeatus; Kraak et al. 2000). Littoral fish density and identity, however, fail to tell the whole story. The structural complexity of some macrophytes negatively impact the foraging rates of some fishes (Warfe and Barmuta 2004). Predation risk and competition can influence the distribution of fish species and age or size structure. For example, small bluegills (Lepomis) spent more time in artificial macrophytes during day than night when predators were present (Shoup et al. 2003), while large bluegill (>200 mm), in contrast used open water, emergent vegetation and submerged vegetation similarly during the day (Paukert and Willis 2002). No single factor controls habitat use of macrophytes by fishes, although macrophyte density, predation risk and prey availability may be the most influential.

Macrophytes also affect the trophic structure and interactions by enhancing fish kills under ice in lakes with long-lasting ice-cover. Canadian studies have shown higher oxygen depletion under ice in shallow lakes with abundant macrophyte biomass (Meding and Jackson 2001). This may, in turn, affect the entire trophic dynamic and water clarity quite substantially in such lakes (Bayley and Prather 2003). Grazing by fishes also may alter the biomass and species composition of submerged macrophytes (Van Donk and Otte 1996). Furthermore, some fishes may not intentionally consume macrophytes, but instead inflict damage at a critical developmental stage when they forage for 
macroinvertebrates (Körner and Dugdale 2003). Despite these known impacts, the complexity of interactions associated with macrophytes and fish seems limitless and warrants further study.

\subsection{In the Wings: Research Areas Worthy of Attention}

Our synthesis of the role of macrophytes in regulating trophic interactions suggests the need for more information to answer several key questions.

\subsubsection{Predictability of Macrophyte Function in Trophic Interactions Across a Climatic Gradient}

Most studies of macrophytes have been confined to North temperate lakes (Jeppesen et al. 2003), while little information exists from warm temperate to tropical lakes (Jeppesen et al.2005). We might expect that higher temperature and favorable growth conditions during winter promote the growth of macrophytes (Rooney and Kalff 2000; Liboriussen et al.2005). We must also consider that floating plants and floating-leaved plants are more prominent in the tropics and subtropics, but these architectures have not been as well studied as submerged plants. In dry areas, a lower water table also might promote macrophyte growth (Blindow et al.1993). However, some macrophyte species, such as Elodea, may be broadly resilient to small increases associated with warming (Mckee et al. 2002). Recent enclosure studies along a climatic gradient in Europe suggested a less positive role of macrophytes on water clarity in warmer versus colder temperate lakes (Moss et al.2004). Bachmann et al. (2002) draw similar conclusions from a cross-comparison of data from Florida lakes. One explanation may be that increased omnivory and a shift to small fish size in warm lakes also increase the use of macrophytes as a habitat for fish, making the plants a less useful refuge for zooplankton and macroinvertebrate grazers (Fig. 3.3; Blanco et al. 2003; Meerhoff et al. 2003; Jeppesen et al. 2005). In the tropics, the life cycles of some fish species are completely coupled to plants (Sazima and Zamprogno 1985; Agonstinho et al. 2003). More comparative studies of submerged, free-floating, floating-leaved and emergent plant communities are needed to understand exactly how architecture influences the dual roles of macrophytes (Fig. 3.2). We advise more studies to consider this temporal scale and to explore how macrophyte age and the ontogeny of other organisms (fish, zooplankton, invertebrates) affect the use of macrophytes as substrates, habitats, or refuges. We especially encourage more studies along climatic gradients to gain needed insight into how climate affects the role of macrophytes in lakes. Such studies are also needed to provide knowledge of how global warming may affect plants and their role in lake ecosystems. 


\subsubsection{Relative Importance of Chemical Ecology Across Trophic Levels}

As others often propose, we also stress the need for collaboration between chemists and ecologists to identify allelopathic compounds of aquatic macrophytes. Such identification would produce incredible potential for experiments that provide definitive answers to testable hypotheses. Experimental evidence for in situ allelopathic activity on epiphyte density is challenging because of natural heterogeneity due to wave action, grazers and macrophyte structure. Thus, no general proof clearly exists for lower epiphyte density on allelopathically active macrophytes (Wium-Andersen 1987; Gross et al. 2003a), but different classes of compounds may differentially affect primary producers. For example, after investigating the allelopathic properties of $\mathrm{Cer}$ atophyllum demersum and Najas marina, Gross et al. (2003b) suggested that water-soluble allelochemicals may inhibit phytoplankton, whereas lipophilic allelochemicals may act through direct cell-cell contact, e.g. against epiphytes. Although difficult, we argue for more field studies that examine allelopathy. For example, we could benefit from more detailed knowledge on how changes in dissolved organic matter (i.e. concentration, composition, or source) or turbidity alter interactions inside and outside macrophyte beds.

\subsubsection{Disproportional Impacts of Certain Invertebrates and Exotic Species}

Fish undoubtedly drive interactions in pelagic communities (Jeppesen 1998). However, in littoral communities, macroinvertebrates, acting as grazers or predators, may be nearly as important in regulating trophic interactions among macrophytes. We recommend that studies continue to focus on invertebrates, especially large individuals such as snails and crayfish. Our literature review also indicated that epiphyton (in combination with grazers) and benthic-pelagic interactions may play a significant role in pushing systems toward a clear or turbid state. We recommend more field experiments that explore this possibility and its relation to lake/wetland management. Last, we encourage wetland scientists and ecologists to examine how macrophytes may facilitate the introduction of exotic species and the implications of macrophytes themselves as exotic species. The introduction of exotic species has the potential to alter primary production and nutrient cycling as well as native biodiversity. Furthermore, climate warming may further facilitate the invasiveness of exotic species. 


\subsection{Returning to Center Stage: Macrophytes are Common Players in Trophic Interactions}

Any wetland textbook will enumerate the many ways in which macrophytes alter biogeochemical cycles. Recognition of the importance of macrophytes in regulating ecosystem processes is not novel (Carpenter and Lodge 1986). The take-home message of our chapter, however, focuses on examining macrophytes at the level of the community and emphasizing the multi-faceted interactions that result. Macrophytes compete with other primary producers, serve as "prey" for herbivores, function as habitat or substrate for multiple trophic levels and may serve as vectors for exotic species. Our chapter broadens the discussion from Jeppesen et al. (1997a) by speculating about how floatingleaved, free-floating and emergent macrophytes may structure interactions beyond what is known for submerged macrophytes. We also discuss how regulation of such interactions could differ between temperate and tropical systems. Regardless of locality, we strongly suggest that the presence of aquatic macrophytes drives interactions within the rest of the food web and determines which trophic interactions play a role in influencing shifts between alternative states.

Acknowledgments We thank Dr. Jos Verhoeven and an anonymous reviewer for guidance on this chapter. M. Bouche, A.M. Poulsen and K. Clovis assisted with our literature search and compilation. A Cullen Faculty Development grant from Southwestern University made R.B.'s participation in the INTECOL symposium possible. E.J. was supported by the research project "Consequences of weather and climate changes for marine and freshwater ecosystems" (CONWOY, 2052-01-0034), funded by the Danish Scientific Research Council and the EU Eurolimpacs project (GOCE-CT-2003-505540).

\section{References}

Abrahams MV, Kattenfeld MG (1997) The role of turbidity as a constraint on predator-prey interactions in aquatic environments. Behav Ecol Sociobiol 40:169174

Agostinho AA, Gomes LC, Ferreira HJ Jr (2003) Relacoes entre macrófitas acquáticas e fauna de peixes. In: Thomas SM, Bini LM (eds) Ecologia e majejo de macrófitas aquáticas. EDUEM, pp 261-279

Bachmann RW, Horsburgh CA, Hoyer MV, Mataraza LK, Canfield DE Jr (2002) Relations between trophic state indicators and plant biomass in Florida lakes. Hydrobiologia 470:219-234

Bais HP, Vepachedu R, Gilroy S, Callway RM, Vivanco JM (2003) Allelopathy and exotic plant invasion: from molecules and genes to species interactions. Science 301:13771380 
Balci P, Kennedy JH (2003) Comparison of chironomids and other macroinvertebrates associated with Myriophyllum spicatum and Heteranthera dubia. J Freshwater Ecol 18:235--247

Bayley SE, Prather CM (2003) Do wetlands exhibit alternate stable states? Submersed aquatic vegetation and chlorophyll in western boreal shallow lakes. Limnol Oceanogr 48:2335-2345

Blanco R, Romo S, Villena MJ, Martinez S (2003) Fish communities and food web interaction in some shallow Mediterranean lakes. Hydrobiologia 506/509:473-480

Blindow I, Andersson G, Hageby A, Johansson S (1993) Long-term pattern of alternative stable states in two shallow eutrophic lakes. Freshwater Biol 30:159-167

Blindow I, Hargeby A, Wagner BMA, Andersson G (2000) How important in the crustacean plankton for the maintenance of water clarity in shallow lakes with abundant submerged vegetation? Freshwater Biol 44:185-197

Brooks JL, Dodson SI (1965) Predation, body size and composition of plankton. Science 150:28-35

Brönmark C (1985) Interactions between epiphytes, macrophytes and herbivores: an experimental approach. Oikos 45:26-30

Brönmark C, Vermaat J (1997) Complex fish-snail-epiphyton interactions and their effects on submerged freshwater macrophytes. In: Jeppesen E, Søndergaard M, Søndergaard $\mathrm{M}$, Christoffersen $\mathrm{K}$ (eds) The structuring role of submerged macrophytes in lakes (Ecological Studies 131) Springer, Berlin Heidelberg New York, pp 47-68

Bry C (1996) Role of vegetation in the life cycle of pike. In: Craig JF (ed) Pike: biology and exploitation. Chapman and Hall, London, pp 45-67

Burks RL, Lodge DM (2002) Cued in: advances and opportunities in freshwater chemical ecology. J Chem Ecol 28:1901-1917

Burks RL, Jeppesen E, Lodge DM (2000) Chemicals from macrophytes and fishes suppress Daphnia growth and alter life history traits. Oikos 88:139-147

Burks RL, Jeppesen E, Lodge DM (2001a) Littoral zone structures as Daphnia refugia against fish predators. Limnol Oceanogr 46:230-237

Burks RL, Jeppesen E, Lodge DM (2001b) Pelagic prey and benthic predators: impact of odonate predation on Daphnia. J N Am Benthol Soc 20:615-628

Burks RL, Lodge DM, Jeppesen E, Lauridsen TL (2002) Diel horizontal migration of zooplankton: costs and benefits of inhabiting the littoral. Freshwater Biol 47:343-365

Carpenter SR, Lodge DM (1986) Effects of submersed macrophytes on ecosystem processes. Aquat Bot 26:341-370

Cattaneo A, Galanti G, Gentinetta S, Romo S (1998) Epiphytic algae and macroinvertebrates on submerged and floating-leaved macrophytes in an Italian lake. Freshwater Biol 39:725-740

Cheruvelil KS, Soranno PA, Madsen JD (2001) Epiphytic macroinvertebrates along a gradient of Eurasian watermilfoil cover. J Aquat Plant Manage 39:67-72

Choi C, Bareiss C, Walenciak O, Gross EM (2002) Impact of polyphenols on growth of the aquatic herbivore Acentria ephemerella. J Chem Ecol 28:2245-2256

Cottenie K, Nuytten J, Michels E, De Meester L (2001) Zooplankton community structure and environmental conditions in a set of interconnected ponds. Hydrobiologia 442: 339-350

Declerck S, Vandekerkhove J, Johansson L, Muylaert K, Conde-Porcuna JM, Van der Gucht K, Pérez-Martínez C, Lauridsen T, Schwenk K, Zwart G, Rommens W, LópezRamos J, Jeppesen E, Vyverman W, Brendonck L, De Meester L (2005) Multi-group biodiversity in shallow lakes along gradients of phosphorus and water plant cover. Ecology 86:1905-1915

Dorn NJ, Wojdak JM (2004) The role of omnivorous crayfish in littoral communities. Oecologia 140:150-159 
Elger A, Willby NJ (2003) Leaf dry matter content as an integrative expression of plant palatability: the case of freshwater macrophytes. Funct Ecol 17:58-65

Elger A, Barrat-Segretain $\mathrm{MH}$, Amoros C (2002) Plant palatability and disturbance level in aquatic habitats: an experimental approach using the snail Lymnaea stagnalis (L.). Freshwater Biol 47:931-940

Englund G, Harms S (2003) Effects of light and microcrustacean prey on growth and investment in Utricularia vulgaris. Freshwater Biol 48:786-794

Erhard D, Gross EM (2005) Do environmental factors influence the composition of potential allelochemicals in the freshwater submersed macrophyte Elodea nuttallii (Hydrocharitaceae)? Verh Int Ver Limnol 29:287-291

Forbes SA (1925) The lake as a microcosm (reprint). INHS Bull 15:537-550

Gaiser EE, Lang KL (1998) Distribution of cladoceran zooplankton among prairie pothole wetlands in northwest Iowa. Lake Reserv Manage 14:37-51

Gopal B, Goel U (1993) Competition and allelopathy in aquatic plant communities. Bot Rev 59:155-210

Gross EM (2003a) Allelopathy of aquatic autotrophs. Crit Rev Plant Sci 22:313-339

Gross EM (2003b) Differential response of tellimagrandin II and total bioactive hydrolysable tannins in an aquatic angiosperm to changes in light and nitrogen. Oikos 103:497-504

Gross EM, Meyer H, Schilling G (1996) Release and ecological impact of algicidal hydrolysable polyphenols in Myriophyllum spicatum. Phytochemistry 41:133--138

Gross EM, Johnson RL, Hairston NG (2001) Experimental evidence for changes in submersed macrophyte species composition caused by the herbivore Acentria ephemerella (Lepidoptera). Oecologia 127:105-114

Gross EM, Feldbaum C, Graf A (2003a) Epiphyte biomass and elemental composition on submersed macrophytes in shallow eutrophic lakes. Hydrobiologia 506/509:559--565

Gross EM, Erhard D, Ivanyi E (2003b) Allelopathic activity of Ceratophyllum demersum L. and Najas marina ssp. intermedia (Wolfgang) Casper. Hydrobiologia 506/509:583589

Guisande C (2000) Effects of zooplankton and conductivity on tropical Utricularia foliosa investment in carnivory. Aquat Ecol 34:137-142

Hann BJ, Zrum L (1997) Littoral microcrustaceans (Cladocera, Copepoda) in a prairie coastal wetland: seasonal abundance and community structure. Hydrobiologia 357:37-52

Hessen DO, Skurdal J, Braathen JE (2004) Plant exclusion of a herbivore; crayfish population decline caused by an invading waterweed. Biol Invasions 6:133-140

Jacobsen L, Perrow MR (1998) Predation risk from piscivorous fish influencing the diel use of macrophytes by planktivorous fish in experimental ponds. Ecol Freshwater Fish 7:78-86

Jacobsen L, Berg S, Jepsen N, Skov C (2004) Does roach behaviour differ between shallow lakes of different environmental state? J Fish Biol 65:135-147

James MR, Hawes I, Weatherhead M (2000) Removal of settled sediments and periphyton from macrophytes by grazing invertebrates in the littoral zone of a large oligotrophic lake. Freshwater Biol 44:311-326

Jeppesen E (1998) The ecology of shallow lakes - biological interactions in the pelagial. DSc dissertation (NERI Report 24), Ministry of Environment and Energy, National Environmental Research Institute

Jeppesen E, Søndergaard M, Søndergaard M, Christoffersen K (eds) (1997a) The structuring role of submerged macrophytes in lakes. (Ecological Studies 131) Springer, Berlin Heidelberg New York

Jeppesen E, Lauridsen TL, Kairesalo T, Perrow MR (1997b) Impact of submerged macrophytes on fish-zooplankton interactions in lakes. In: Jeppesen E, Søndergaard M, 
Søndergaard $M$, Christoffersen $\mathrm{K}$ (eds) The structuring role of submerged macrophytes in lakes (Ecolological Studies 131) Springer, Berlin Heidelberg New York, pp 91-114

Jeppesen E, Jensen JP, Søndergaard M, Lauridsen T (1999) Trophic dynamics in turbid and clearwater lakes with special emphasis on the role of zooplankton for water clarity. Hydrobiologia 408/409:217-231

Jeppesen E, Søndergaard M, Søndergaard M, Christoffersen K, Theil-Nielsen J, Jurgens K (2002) Cascading trophic interactions in the littoral zone: an enclosure experiment in shallow Lake Stigsholm, Denmark. Arch Hydrobiol 153:533-555

Jeppesen E, Jensen JP, Jensen C, Faafeng B, Hessen DO, Søndergaard M, Lauridsen T, Brettum P, Christoffersen K (2003) The impact of nutrient state and lake depth on topdown control in the pelagic zone of lakes: a study of 466 lakes from the temperate zone to the arctic. Ecosystems 6:313-325

Jeppesen E, Jensen JP, Søndergaard M, Fenger-Grøn M, Bramm ME, Sandby K, Møller PH, Rasmussen HU (2004) Impact of fish predation on cladoceran body weight distribution and zooplankton grazing in lakes during winter. Freshwater Biol 49:432447

Jeppesen E, Søndergaard M, Mazzeo N, Meerhoff M, Branco CC, Huszar V, Scasso F (2005) Lake restoration and biomanipulation in temperate lakes: relevance for subtropical and tropical lakes. In: Reddy V (ed) Tropical eutrophic lakes: their restoration and management. pp 331-359

Jeppesen E, Pekcan-Hekim Z, Lauridsen TL, Søndergaard M, Jensen JP (2006) Habitat distribution of fish in late summer: changes along a nutrient gradient in Danish lakes. Ecol Freshwater Fish (in press)

Jones JI, Sayer CD (2003) Does the fish-invertebrate-periphyton cascade precipitate plant loss in shallow lakes? Ecology 84:2155-2167

Jones JI, Waldron S (2003) Combined stable isotope and gut contents analysis of food webs in plant dominated, shallow lakes. Freshwater Biol 48:1396-1407

Jones JI, Moss B, Young JO (1997) Interactions between periphyton, nonmolluscan invertebrates and fish in standing freshwaters. In: Jeppesen E, Søndergaard M, Søndergaard $\mathrm{M}$, Christoffersen $\mathrm{K}$ (eds) The structuring role of submerged macrophytes in lakes (Ecological Studies 131) Springer, Berlin Heidelberg New York, pp 69-90

Jones JI, Moss B, Eaton JW, Young JO (2000) Do submerged aquatic plants influence periphyton community composition for the benefit of invertebrate mutualists? Freshwater Biol 43:591-604

Jones JI, Young JO, Eaton JW, Moss B (2002) The influence of nutrient loading, dissolved inorganic carbon and higher trophic levels on the interaction between submerged plants and periphyton. J Ecol 90:12-24

Körner S, Dugdale T (2003) Is roach herbivory preventing re-colonization of submerged macrophytes in a shallow lake? Hydrobiologia 506/509:497-501

Körner S, Nicklisch A (2002) Allelopathic growth inhibition of selected phytoplankton species by submerged macrophytes. J Phycol 38:862-871

Kraak SBM, Bakker TCM, Hocevar S (2000) Stickleback males, especially large and red ones, are more likely to nest concealed in macrophytes. Behaviour 137:907-919

Lach L, Britton DK, Rundell RJ, Cowie RH (2000) Food preference and reproductive plasticity in an invasive freshwater snail. Biol Invasions 2:279-288

Lauridsen TL, Pedersen LJ, Jeppesen E, Søndergaard M (1996) The importance of macrophyte bed size for cladoceran composition and horizontal migration in a shallow lake. J Plank Res 18:2283-2294

Lewin WC, Okun N, Mehner T (2004) Determinant of the distribution of juvenile fish in the littoral area of a shallow lake. Freshwater Biol 49:410-424 
Lewis WM (2001a) Wetlands explained: wetland science, policy and politics in America. Oxford University Press, New York

Lewis DB (2001b) Trade-offs between growth and survival: responses of freshwater snails to predacious crayfish. Ecology 82:758-765

Liboriussen L, Landkildehus F, Meerhoff M, Bramm ME, Søndergaard Mo, Christoffersen K, Richardson K, Søndergaard Ma, Lauridsen T, Jeppesen E (2005) Global warming: design of a flow-through shallow lake mesocosm climate experiment. Limnol Oceanogr Methods 3:1-9

Lindeman RL (1942) The trophic-dynamic aspect of ecology. Ecology 23:399-418

Lindén E, Lehtiniemi M (2005) The lethal and sublethal effects of the aquatic macrophyte Myriophyllum spicatum on Baltic littoral planktivores. Limnol Oceanogr 50:405-411

Lodge DM, Kershner MW, Aloi JE, Covich AP (1994) Effects of an omnivorous crayfish (Orconectes rusticus) on a freshwater littoral food web. Ecology 75:1265-1281

Lombardo P (1997) Predation by Enallagma nymphs (Odonata, Zygoptera) under different conditions of spatial heterogeneity. Hydrobiologia 356:1-9

Lombardo P, Cooke GD (2002) Consumption and preference of selected food types by two freshwater gastropod species. Arch Hydrobiol 155:667-685

Marklund O, Blindow I, Hargeby A (2001) Distribution and diel migration of macroinvertebrates within dense submerged vegetation. Freshwater Biol 46:913-924

Mckee D, Hatton K, Eaton J, Atkinson D, Atherton A, Harvey I, Moss B (2002) Effects of simulated climate warming on macrophytes in freshwater microcosm communities. Aquat Bot 74:71-83

Meding ME, Jackson LJ (2001) Biological implications of empirical models of winter oxygen depletion. Can J Fish Aquat Sci 58:1727-1736

Meerhoff M, Mazzeo N, Moss B, Rodríguez-Gallego L (2003) The structuring role of freefloating versus submerged plants in a subtropical shallow lake. Aquat Ecol 37:377-391

Molisch H (1937) Der Einfluss einer Pflanze au die Anderd-Allelopathie. Fischer, Jena

Moss B, Stephen D, Balayla DM, Bécares E, Collings SE, Fernández-Aláez C, FernándezAláez M, Ferriol C, García P, Gomá J, Gyllström M, Hansson L-A, Hietala J, Kairesalo T, Miracle MR, Romo S, Rueda J, Russell V, Ståhl-Delbanco A, Svensson M, Vakkilainen K, Valentín M, Van de Bund WJ, Van Donk E, Vicente E, Villena MJ (2004) Continental-scale patterns of nutrient and fish effects on shallow lakes: synthesis of a pan-European mesocosm experiment. Freshwater Biol 49:1633-1649

Mulderij G, Van Donk E, Roelofs JGM (2003) Differential sensitivity of green algae to allelopathic substances from Chara. Hydrobiologia 491:261-271

Mulderij G, Mooij WM, Van Donk E (2005a) Allelopathic growth inhibition and colony formation of the green alga Scenedesmus obliquus by the aquatic macrophyte Stratiotes aloides. Aquat Ecol 39:11-21

Mulderij G, Mooij WM, Smolders AJP, Van Donk E (2005b) Allelopathic inhibition of phytoplankton by exudates from Stratiotes aloides. Aquat Bot 82:284-296

Murphy JE, Beckmen KB, Johnson JK, Cope RB, Lawmaster T, Beasley VR (2002) Toxic and feeding deterrent effects of native aquatic macrophytes on exotic grass carp (Ctenopharyngodon idella). Ecotoxicology 11:243-254

Nurminen L, Horppila J (2002) A diurnal study on the distribution of filter feeding zooplankton: effect of emergent macrophytes $\mathrm{pH}$ and lake trophy. Aquat Sci 64:198-206

Nurminen L, Horppila J, Lappalainen J, Malinen T (2003) Implications of rudd (Scardinius erythropthalmus) herbivory on submerged macrophytes in a shallow eutrophic lake. Hydrobiologia 506/509:511-518

Nyström P, Pérez JR (1998) Fish predation on the common pond snail (Lymnaea stagnalis): the effect of habitat complexity and snail size on foraging efficiency. Hydrobiologia 368:201-208 
Paukert CP, Willis DW (2002) Seasonal and diel habitat selection by bluegills in a shallow natural lake. Trans Am Fish Soc 131:1131-1139

Persson L, Crowder LB (1997) Fish-habitat interactions mediated via ontogenetic niche shifts. In: Jeppesen E, Søndergaard M, Søndergaard M, Christoffersen K (eds) The structuring role of submerged macrophytes in lakes. (Ecolological Studies 131) Springer, Berlin Heidelberg New York, pp 3-23

Pflugmacher S (2002) Possible allelopathic effects of cyanotoxins, with reference to microcystin-LR, in aquatic ecosystems. Environ Toxicol 17:407-413

Phillips GL, Eminson D, Moss B (1978) A mechanism to account for macrophyte decline in progressively eutrophicated freshwaters. Aquat Bot 4:103-126

Priyadarshana T, Aeaeda T, Manatunge J (2001) Foraging behaviour of planktivorous fish in artificial vegetation: the effects on swimming and feeding. Hydrobiologia 442:231-239

Rantala MJ, Ilmonen J, Koskimäki J, Suhonen J, Tynkkynen K (2004) The macrophyte, Stratiotes aloides, protects larvae of dragonfly Aeshna viridis against fish predation. Aquat Ecol 38:77-82

Roberts E, Kroker J, Körner S, Nicklisch A (2003) The role of periphyton during the recolonization of shallow lake with submerged macrophytes. Hydrobiologia 506/509: $525-530$

Rodríguez CF, Bécares E, Fernández-Aláez M (2003) Shift from clear to turbid phase in Lake Chozas (NW Spain) due to the introduction of American red swamp crayfish (Procambarus clarkii). Hydrobiologia 506/509:421-426

Romare P, Berg S, Lauridsen T, Jeppesen E (2003) Spatial and temporal distribution of fish and zooplankton in a shallow lake. Freshwater Biol 48:1353-1362

Rooney N, Kalff J (2000) Inter-annual variation in submerged macrophyte community biomass and distribution: the influence of temperature and lake morphometry. Aquat Bot 68:321-335

Rowell K, Blinn DW (2003) Herbivory on a chemically defended plant as a predation deterrent in Hyalella azteca. Freshwater Biol 48:247-254

Rybak JI, Weglenska T (2003) Temporal and spatial changes in the horizontal distribution of planktonic crustacea between vegetated littoral zone and the zone of open water. Pol J Ecol 51:205-218

Sagrario MDG, Balseiro E (2003) Indirect enhancement of large zooplankton by consumption of predacious macroinvertebrates by littoral fish. Arch Hydrobiol 158:551-574

Sazima I, Zamprogno C (1985) Use of water hyacinth as shelter, foraging pace, and transport by young piranhas, Seeasalmus spilopleura. Environ Biol Fish 12:237-240

Scheffer M (1998) Community dynamics of shallow lakes. Chapman and Hall, London

Shoup DE, Carlson RE, Heath RT (2003) Effects of predations risk and foraging return on the diel use of vegetated habitat by two size-classes of bluegills. Trans Am Fish Soc 132:590-597

Skov C, Berg S (1999) Utilization of natural and artificial habitats by YOY pike in a biomanipulated lake. Hydrobiologia 408/409:115-122

Skov C, Berg S, Jacobsen L, Jepsen N (2002) Habitat use and foraging success of $0+$ pike (Esox lucius L.) in experimental ponds related to prey fish, water transparency and light intensity. Ecol Freshwater Fish 11:65-73

Smart AC, Harper DM, Malaisse F, Schmitz S, Coley S, Gouder de Beauregard A-C (2002) Feeding of the exotic Louisiana red swamp crayfish, Procambarus clarkii (Crustacea, Decapoda), in an African tropical lake: Lake Naivasha, Kenya. Hydrobiologia 488:129-142

Teal JM (1962) Energy flow in the salt marsh ecosystem of Georgia. Ecology 43:614-624 
Tolonen KT, Hämäläinen H, Holopainen IJ, Karjalainen J (2001) Influences of habitat type and environmental variables on littoral macroinvertebrate communities in a large lake system. Arch Hydrobiol 152:39-67

Vadeboncoeur Y, Vander Zanden MJ, Lodge DM (2002) Putting the lake back together: reintegrating benthic pathways into food web models. Bioscience 52:44-55

Valley RD, Bremigan MT (2002) Effects of macrophyte bed architecture on largemouth bass foraging: implications of exotic macrophyte invasions. Trans Am Fish Soc 131:234-244

Van de Meutter F, Stoks R, De Meester L (2004a) Behavioral linkage of pelagic prey and littoral predators: microhabitat selection by Daphnia induced by damselfly larvae. Oikos 107:265-272

Van de Meutter F, Stoks R, De Meester L (2004b) Spatial avoidance of littoral and pelagic invertebrate predators by Daphnia. Oecologia, DOI: $10.1007 / \mathrm{s} 00442-004-1738-5$

Van Donk E, Bund WJ van de (2002) Impact of submerged macrophytes including charophytes on phyto- and zooplankton communities: allelopathy versus other mechanisms. Aquat Bot 72:261-274

Van Donk E, Otte A (1996) Effects of grazing by fish and waterfowl on the biomass and species composition of submerged macrophytes. Hydrobiologia 340:285-290

Vono V, Barbosa FAR (2001) Habitats and littoral zone fish community structure of two natural lakes in southeast Brazil. Environ Biol Fish 61:371-379

Warfe DM, Barmuta LA (2004) Habitat structural complexity mediates the foraging success of multiple predator species. Oecologia 141:171-178

Weaver MF, Magnuson JJ, Clayton MK (1997) Distribution of littoral fishes in structurally complex macrophytes. Can J Fish Aquat Sci 54:2277-2289

Williams AE, Moss B, Eaton J (2002) Fish induced macrophyte loss in shallow lake: topdown and bottom-up processes in mesocosm experiments. Freshwater Biol 47:22162232

Winfield I (2004) Fish in the littoral zone: ecology, threats and management. Limnologica 34:124-131

Wium-Andersen S (1987) Allelopathy among aquatic plants. Arch Hydrobiol Beih Erg Limnol 27:167-172 